\title{
Influence of Perceived Service Quality on Customer Loyalty
}

\author{
Madumere Humphrey Ikenna ${ }^{\mathrm{a}, *}$, Dickson Ben Uche ${ }^{\mathrm{b}}$, Agu Godswill Agu ${ }^{\mathrm{c}}$ \\ ${ }^{a}$ Department of Marketing, Nnamdi Azikiwe University, Awka, Nigeria \\ ${ }^{b}$ Department of Marketing, Evangel University, Akaeze, Nigeria \\ ${ }^{c}$ Department of Marketing, Abia State University, Uturu, Nigeria
}

\begin{abstract}
The purpose of this was to investigate the relationship between perceived service quality and customer loyalty in the road transport industry in Nigeria. Leveraging the RATER service quality model, only reliability, tangibles and responsiveness were explored. Participants were drawn from the customer base of organized road transport firms operating in the South East of Nigeria. Being a quantitative survey, results from 318 valid responses were analyzed with SPSS version 21 . Findings indicate that the three constructs (reliability, tangibles, and responsiveness) are significant predictors of customer loyalty, with reliability having the greatest influence, followed by responsiveness and tangibles. The study recommends steady monitoring of service quality as a step towards customer loyalty in the highly competitive road transport industry in Nigeria.
\end{abstract}

Keywords: Service quality; Reliability; Tangibles; Responsiveness; RATER model.

\section{Introduction}

The Nigerian road transport segment has remained the major contributor to the Gross Domestic Product (GDP) of the Nation from transport sub- sector over the years. For the past twenty to thirty years now, the road transport mode accounts for more than 90 percent of the sub-sector's contribution to GDP (NBS, 2012; Agu, 2015; Ayantoyinbu \& Ekundayo, 2015). Indeed, competition in this sector has remained intense since operators of various levels and forms easily find their ways into the sector. Compared to other modes recognized by Nigeria Bureau of Statistics (rail transport, pipelines, water transport and air transport), the road transport segment is a common means of transportation by majority of the Nigerian population (CBN Statistical Bulletin, 2012; Ogwo and Agu, 2015; Ayantoyinbu \& Ekundayo, 2015). This is largely owing to the inaccessible nature of the rail system and the costly nature of the air transport, relative to the per capita income of the majority in the country.

Indeed, despite the value placed by road transport customers on consistent good service quality provision that are reliable, assured, reasonably tangibilized, empathic and responsive, operators in the Nigerian road transport industry seem to give less attention to its key dimensions. This results in customer dissatisfaction, dissonance and switching of service provider. In many instances, customers patronize different operators in a single trip in a quest for the expected service quality experience. It is more worrisome when firms that are perceived by customers to be more organized than the road-side, open-market operators, display an obvious negligence to critical service quality factors that should attract customer loyalty. In fact, as rightly observed by Agu (2015), many Nigerian middle class road transport customers are ready to pay for good services if they are available, the cost notwithstanding. Exposing the power of consistent service quality provision in retaining customers becomes imperative, as that will draw the attention of operators to the inherent benefits.

In the global arena, Nigerian organized road transport firms may rank very low when measured with globally known service quality models. This is because their present marketing efforts seem to pay little or no attention to these global

\footnotetext{
* Corresponding author.

E-mail address: madumerehumphreyikenna@gmail.com (Madumere Humphrey Ikenna)
} 
service quality dimensions. There is the need to re-strategize to drive and win customer loyalty from these globally recognized service quality dimensions. Moreover, the Nigerian Road Transport Industry has grown to the level that it should develop and make available periodic ranking of the organized road transport firms from customer service quality perception angle (customer satisfaction index). Since none exists in the Nigerian road transport marketing literature at the moment, customers are left in the dark when it comes to patronage decisions based on service quality.

Reviewed literature shows that studies on the road transport sector of Nigeria have focused more on issues such as complaints handling, patronage factors and contribution to GDP (Agu \& Okpara, 2015; Ogwo \& Agu, 2015; Madumere, 2015; Ayantoyinbu \& Ekundayo, 2015),constraints (Aworem, 2009; Aderemo, 2010; Ogwo \& Agu, 2015), single firm study (Agu \& Ogbuji, 2008) and single city study (Nwachukwu, 2014; Madumere \& Agu, 2015; Kalu \& Agu, 2013). Thus, there is no known study that measured customer loyalty as a function of perceived service quality using known models. It is this gap that this present study stands to close in view of the importance of these dimensions in the global competitive ranking of service providers. The study therefore, seeks to use the RATER model of service quality to establish the relationship between customers' perception of service quality (specifically, reliability, tangibility and responsiveness) and their loyalty intention. Specifically, the following objectives were actualized in this study:

1. To ascertain the nature of relationship between perceived service reliability and customer loyalty intention

2. To ascertain whether significant, positive relationship exists between perceived service tangibles and customer loyalty intention.

3. To ascertain the nature of relationship between perceived service responsiveness and customer loyalty intention.

\section{Scope of the Study}

The geographical setting of this research study is the South East Nigeria, which comprises Abia, Imo, Anambra, Enugu and Ebonyi States, with specific attention on the cities known for heavy presence of organized road transport firms. Thus, the cities covered were Owerri, Enugu, Onitsha, Abakaliki and Aba. This study is domiciled in the area of consumer behaviour with major emphasis on service quality, consumer perception and loyalty intentions. The units of analysis in the study were the customers of four organized road transport firms in the zone that were in long distant shuttle service and are managed by private bodies or individuals. These transport firms were classified by Agu (2015) as "organized", since they have clearly defined management structure, trained and regular staff members, over fifty modern buses, registered business premises or terminals, clearly defined vision and mission statements in their transport business activities, and formal or informal approaches to customers' complaints handling.

Furthermore, while the study is based on the RATER model of service quality, only reliability, tangibles, and responsiveness are covered in this study.

\section{Literature Review}

\subsection{The nature of transportation services in Nigeria}

Over the years, the service sector has remained a leading sector in most economies of the world including Nigeria (Agu, 2015; Anyanwu, 2013; Agbonifoh et al, 2007; Kotler and Keller, 2007; Etzel et al, 2001). The scope of services as documented by Stanton (1970), Etzel et al (2001) and Kotler and Keller (2007) in Agu (2015) covers housing, household operations, recreation and entertainment, personal care, medical and healthcare, private education, professional business services (legal, accounting, research, etc), financial services, transportation, insurance and communications. This study however, focuses on the transportation industry.

According to Agu (2015), many scholars have defined transportation in many ways. Many have viewed its relevance to economic development (Rodrigue \& Nottemboom, 2013; Onolememe, 2013; Njoku, 2009; Ikpechukwu \& Ureal, 2012, Ogwo \& Agu, 2016). Some others look at it from its status as a key element of the physical distribution function of marketing that makes the movement of goods from the point of production to the point of consumption 
and or resell possible (Anyanwu, 2003; Agbonifoh, et al., 2007; Okpara, 2012; Onah \& Thomas, 2004; Inyanga, 2004; Olakunori, 2006; Kotler \& Keller, 2007). From whatever angle, transportation occupies a strategic position in the economic and social activities of people (Agu, 2015).

Transportation means the movement of goods and passenger from one place to another. Agu (2015) asserts that it is generally grouped into two broad types: based on the object carried and based on the means of transport. When viewed from the object carried, there are the transport of people, which can be done using cars, buses, coaches, automobiles etc, and the transport of goods, which is done by the use of trucks, vans, pickups, etc. Based on the means of transport, there are, according to Onah and Thomas (2004) road transport, rail transport, air transport, water transport and pipeline transport. This study covers only the transport of people and the road transport segment in Nigeria.

As noted earlier, the Nigerian Road Transport System was characterized by the use of old, outdated, risky and overloaded cars, buses and coasters in moving people within short and long distances. The system was also characterized by the presence of touts used as drivers and loading assistants (conductors) who abused, insulted and treated passengers disrespectfully. From the beginning of an average journey to its end, passengers were left in the hands of fate as the reckless drivers who cared only for the money they would make through the number of trips made and cared little or not about the safety, satisfaction and comfort of passengers, were ready to do anything possible to achieve their aims. Though this system is not yet completely off in the road transport system of the country, efforts have been made to attract organized corporate organizations, which render modern, customer-oriented road transport services to the teaming Nigerian population who travel daily. Today, the open-market road transport services and the organized transport services coexist, each group serving a particular class or segment of the total market.

According to Chidoka (2009), the road transport system in Nigeria accounts for over $75 \%$ of mobility needs of the country. The national network is currently estimated to be $194,200 \mathrm{~km}$ of which $34,120 \mathrm{~km}(17.6 \%)$ are federal, $3050 \mathrm{~km}(15.7 \%)$ are State, while $129,580 \mathrm{~km}(66.7 \%)$ are local and rural roads (www.wikipedia.com,2011). Of these figures, $36900 \mathrm{~km}$ of federal and state main roads representing $19 \%$ are paved, while $25,700 \mathrm{~km}(13 \%)$ are unpaved. In addition, $21,900 \mathrm{~km}, 72,800 \mathrm{~km}$ and $35,900 \mathrm{~km}$ representing $11 \%, 38 \%$ and $19 \%$ are urban roads, main rural roads and village access roads respectively (CBN Statistical Bulletin, 2003). In fact, the CIA World Fact Book (2009) stressed that Nigeria has the largest road network in West Africa and the second largest South of the Sahara. It is sad to note that even the federal road networks are largely unmotorable, how much less the state and local roads that have the largest shares of the road network system in the country.

Nevertheless, the road transport segment has continued to lead other segments of the transport system in their contributions to the Gross Domestic Product (GDP) of the nation. In 2009, over $90 \%$ of the contribution of the transport sector to Nigeria's GDP was from the road segment. The CBN Statistical Bulletin (2011) shows that between 2001 and 2005, the aviation segment contributed $0.04 \%, 0.05 \%, 0.04,0.04$ and 0.05 respectively, while ocean contributed $0.19 \%, 0.21 \%, 0.24 \%, 0.26 \%$ and $0.20 \%$ respectively. The bulk of the contributions of the transport sector to GDP since 1981 come from the road segment with $5.93 \%$ as the highest ever in 1982, 2.77\%, $2.97 \%, 2.96 \%, 4.08 \%$ and $5.29 \%$ from 2001 to 2005 respectively.

Modern (1991) as cited in Inyanga, (2004) identified the factors that influence patronage of certain transportation carriers as cost, speed, reliability, accessibility, security, dependability, customer service, distance, operational capability etc. the road transport segment faces serious challenges such as: poor road facilities, weak regulatory framework, increasing rate of accident, presence of many unorganized operators etc. These problems cause dissatisfaction on customers, which also result in complaints.

The Nigerian Road Transport Industry is becoming increasingly competitive, as the operators have continued to learn and adopt strategic business approaches in their services. For instance, ABC transport Plc has safety as its cardinal focus and the company monitors the speed limit of its busses through speed tracking. Most of the organized bus operators have vehicles that are sound and convenient for passengers (Aderamo, 2012; Akeem, 2010; Ogwudo, 2011; Njim \& Udosen, 2007, Agu \& Okpara, 2015, Ogwo \& Agu, 2016). Each operator maintains a share of the total market with $\mathrm{ABC}$ Transport being the leader of the industry and the only quoted road transport firm in the country. 


\subsection{Service quality in the transport industry}

Etzel, Walker and Stanton (2007) defined services as identifiable, intangible activities that are the main object of a transaction designed to provide want-satisfaction to customers. In Kalu (2015), Lovelock defined services as all the businesses or enterprises not concerned with the creation of manufactured commodities. Agbonifoh, Ogwo, Nnolim and Nkamnebe (2007) noted that the auxiliary services, which are also known as customer services, after sales services or support service are incidental and additional services to a corporal item of trade. Agu (2015) therefore, observed that no transport firm can endure the heat of rivalry in the Nigerian road transport subsector today if auxiliary, customer services are ignored. This is why all or some of the organized road transport firms have customer service units.

Okpara (2012) recommended that service providers ought to manifest marketing promptitude; positioned enthusiastically to deliver services to customers when a demand exists. However, Agu (2015) noted that the elusive state of services has made it intricate for clients to state exactly the quality level of services paid for. For Anyanwu (2008), quality statements (taken to mean good quality, although allowance must be made for bad quality) can only be made when a customer has experienced two standards of relative elements. In simple terms therefore, service Quality (SQ) is an evaluation of how well a delivered service matches customers' hopes. BusinessDictionary.com (2013) explained that service dealing operators often measure the service quality provided to their customers in order to advance their service, to promptly spot nuisance, and to better assess customer satisfaction".

For effective management of service quality, Madumere (2019) pointed out that the firm should help patrons create prospects, gauge the prospect level of its target market, and endeavor to uphold reliable service quality at or above the prospects level. Parasuraman, Zeithaml and Berry (1985) as cited in Kotler and Keller (2007), Anyanwu (2008) and Agu (2015), identified a service quality model that highlights the main requirements for delivering high quality. The model identifies the five gaps (SERVQUAL) that cause ineffective. The gaps are as follows:-

a. Gap between consumer expectation and management perception: This is because management does not always appropriately perceive what customers desire.

b. Gap between management perception and service-quality expectation: This shows that management might properly recognize customers' wants but not set a recital standard.

c. Gap between service-quality specifications and service delivery: Workers might be inadequately skilled, or capable or reluctant to meet the standard.

d. Gap between service delivery and external communications: Customer expectations are affected by statements made by company representatives and their advertisements.

e. Gap between perceived service and expected service. This occurs when the consumer misperceives the service quality.

This model was redefined in 1990 by the originators as the RATER model. Thus, the RATER model highlights five areas that customers generally consider important when they use a service - reliability (R), assurance (A), tangibility (T), empathy (E) and responsiveness (R). Here they are discussed in line with the transport industry.

Reliability: this is the ability of a transport firm to provide the service it promised consistently, accurately, and on time. In other words, when considering whether a transport firm is reliable, customers look out for those transporters that are consistent, accurate and time conscious in the delivery of their avowed promises.

Assurance: Transport customers look out for transport firms whose team of staff display adequate knowledge, skills, and credibility and posses the ability to use this expertise to inspire trust and confidence on the customers.

Tangibles: This has to do with the physical evidence of the transport firms. This may include the offices, equipment, employees' appearance, nature of buses, and the communication and marketing materials used.

Empathy: This aspect of service quality deals with the relationship between employees and customers. It could mean rendering personalized services to customers. In the transport firm therefore, it may involve the feeling by customers 
(passengers) of being recognized by the staff (desk officers, drivers and loaders) and feeling of being treated courteously and politely by the staff.

Responsiveness: This is the ability of the service provider to provide a quick, high quality service to their customers. In this, the passengers look for transport firms that defile all odds to provide their services timely. For instance, some transport companies have scheduled time of movement from the station. Any delay may attract dissatisfaction of the customers.

\subsection{The concept of customer loyalty}

Madumere (2019) noted that customer loyalty comprises both customers' attitudes and behaviors. Cronin and Taylor (1992), Narayandas (1996), Prus and Brandt (1995) and Zeithaml, Berry, and Parasuraman (1996) noted that customers' attitudinal component represents notions like repurchase plan or purchasing extra products or services from the same company, enthusiasm to advocate the company to others, expression of such dedication to the company by demonstrating an opposition to switching to another contenders. It also includes willingness to pay a price premium (Madumere, 2019). On the other hand, the behavioral facet of customer loyalty represents actual repeat purchase of products or services that includes purchasing more and different products or services from the same company, suggesting the company to others and reflecting a long-term choice probability for the brand (Feick, Lee and Lee, 2001). Customer loyalty expresses an anticipated conduct connected to the product or service or to the company.

Pearson (1996) cited in Madumere (2019) has defined customer loyalty as the mindset of the customers, who hold favorable attitudes toward a company, commit to repurchase the company's product or service and recommend the product or service to others. Customer loyalty is very significant in the creation and maintenance of competitive advantage in the service industry.

It therefore follows that for a guaranteed customer loyalty to a firm, the customer must be made to develop strong positive perception towards the firm, its products, staff, physical evidence, etc. Thus, Hawking, Best and Coney (2009) observed that perception is the critical activity that links the individual consumer to group, situation and marketing influences. It is the process of attaining awareness or understanding and interpreting sensory information. Perception is a reaction to the signals in the nervous system resulting from physical stimulation of the sense organ. As noted by Kotler and Keller (2007), perception depends not only on the physical stimuli, but also on the stimuli's relation to the surrounding field and on conditions within the individual. The existence of the three stages of the perceptual process - selective attention, selective distortion, and selective retention leads to different perceptions of same object by consumers. It therefore becomes imperative on service providers to create, position, and maintain such a status that will lead to positive perception and reaction by consumers.

A loyal customer also remains faithful to a firm and supports it to grow profitably. Henning (2010) and Hayes (2012) have identified three components of customer loyalty as advocacy loyalty, retention loyalty and purchasing loyalty. They noted that effective management of advocacy loyalty would help drive "new customers" growth. Managing the purchasing loyalty will drive "existing customers" growth by increasing average revenue per user (ARPU). Managing retention loyalty will drive overall size of the customer base. In all, when service failure occurs repeatedly, it results in negative perception of the service quality and delivery, which may result in poor marketing performance.

\subsection{Empirical review}

Saravanakumar and Jayakrishnan (2014) studied the effect of service quality of Primary Agricultural co-operative Bank and customer loyalty of 415 customers from a particular Primary Agricultural Cooperative Bank at Thanjavur District, Tamil Nadu. They used service quality dimension (tangibility, reliability, responsiveness, assurance and empathy) to measure service quality of the bank. Customer loyalty was measured with five statements. The collected data were analyzed with descriptive statistics, correlation and regression analysis. The result showed that service quality had the impact on customer loyalty. However, it was disclosed that empathy and reliability were the dimensions that significantly influenced customer loyalty. It was judged that the bank must improve the services in terms of the tangibility, responsibility and assurance. 
Specifically, the study of Duodu and Amankwah (2011) examined the determinants of satisfaction and the effects of customer satisfaction on behavioural intentions of consumers in Ghana's insurance industry (GII), as well as the influence of background data on the relationship between satisfaction and behaviour intention. The study was a crosssectional survey that used self-administered structured questionnaire to the target population of customers of insurance companies in Ghana. Out of the one thousand and one hundred questionnaire administered, one thousand and fifty-one usable questionnaire were obtained constituting $87.6 \%$ for analysis. Structural Equation Modeling (SEM) approach was used to analyze and test relationships among variables. The study found that reliability and responsiveness are functional quality dimensions that were found to have significant impact on customer satisfaction in GII. Again, Technical quality, Price, and image quality were found to be factors that do not significantly affect customer satisfaction determination in GII.

Again, Derkota and Dahal (2016) used factor analysis and multiple regression to assess the opinions of 375 bank customers in Kathmardn, Nepal. Findings show that tangibility, reliability, responsiveness, empathy and product have significant positive impact on satisfaction and loyalty. Also, Kofi, Zakari and Ajara (2013) assessed the impact of service quality on customer loyalty in the hotel industry in China. The SERVQUAL Model, Questionnaire and Interview were used to study 50 customers and 5 staff of 4 hotels. All variables but for tangibility have significant impact on customer loyalty. Kumar (2015) assessed the effects of service quality on Indian customers' loyalty to telecom firms and the mediating role of customer satisfaction. They used the exploratory factor analysis to show that all the RATER components, apart from reliability have significant effect on customer loyalty.

In addition, Leninkumar (2016) carried out a study involving 300 bank customers in Sri Lanka to find out the effect of service quality on customer loyalty using the Rater Model. The study found out in a multiple regression that tangibles, reliability and empathy have significant positive impact while assurance and responsiveness are not significant predictors of customer loyalty. Again, Kheng, Osman, Ramayeh and Mosahab (2010) in a study of 238 bank customers in Malaysia found that only reliability, empathy and assurance have significant impact on customer loyalty while tangibility and responsiveness are not significant predictors.

Based on the argument above, the following hypotheses are developed:
$\mathrm{H}_{1}$ : There is a significant, positive relationship between perceived service reliability and customer loyalty intention.
$\mathrm{H}_{2}$ : There is a significant, positive relationship between perceived service tangibles and customer loyalty intention.
$\mathrm{H}_{3}$ : There is a significant, positive relationship between perceived service responsiveness and customer loyalty intention.

\section{Methods}

The researcher adopted the survey research design in this study. Customers of the organized road transport firms operating in the South East, Nigeria formed the population of the study. The sample size was ascertained using the Top-man formula as cited by Ogbuji (2013) thus: $\mathrm{n}=\mathrm{Z}^{2}(\mathrm{Pq}) / \mathrm{e}^{2}$. Based on this, the sample size was approximated to 340 respondents. Collected data were analyzed using descriptive and inferential statistics. Stated hypotheses were tested using Simple Regression Analysis at 0.05 level of significance and one-way Analysis of Variance (ANOVA) in SPSS version 21, after items were subjected to cronbach's alpha test for reliability and experts' check for validity. Scales were adopted from Agu and Okpara (2015). 


\section{Result and Discussions}

\subsection{Data presentation and analyses}

\subsubsection{Nature of Distribution and Retrieval of Research Instrument}

The research instrument used in this study was structured questionnaire which was administered on randomly selected customers of the four organized road transport firms used for the study. The table below shows how the 318 copies of the questionnaire were distributed and retrieved.

Table 1. Distribution and Retrieval of Instrument

\begin{tabular}{llllll}
\hline Transport Firms & ADPT & Copies Issued & $\begin{array}{l}\text { Copies Retrieved and } \\
\text { Used }\end{array}$ & Copies Lost & $\begin{array}{l}\text { Percentage } \\
\text { of Used }\end{array}$ \\
\hline ABC & 194 & 72 & 68 & 4 & 21.00 \\
Chisco & 227 & 84 & 81 & 3 & 26.00 \\
The Young & 278 & 103 & 96 & 7 & 30.00 \\
GUO & 219 & 81 & 73 & 8 & 23 \\
Total & 918 & 340 & $318(94 \%)$ & $22(06 \%)$ & 100.00 \\
\hline
\end{tabular}

Source: Field survey, 2020.

Table 1 shows that the copies of questionnaire administered on customers of the road transport firms were based on the Average Daily Passenger Traffic (ADPT) of the firms as recorded in chapter three. Copies issued were ratios of the ADPT figures. A total of 340 copies were issued. 72, 84, 103 and 81 copies were issued to customers of ABC, Chisco, The Young, and GUO, respectively. Of these figures, a total of $318(94 \%)$ copies were retrieved - 68(94\%), 81(96\%), $96(93 \%)$ and 73(90\%) respectively for ABC, Chisco, The Young, and GUO. Again, a total of 22 copies, representing $6 \%$ were lost $-4(6 \%), 3(4 \%), 7(7 \%)$ and $8(10 \%)$ for $\mathrm{ABC}$, Chisco, The Young and GUO respectively. Thus, further analyses were based on the 318 copies retrieved and used.

\subsubsection{Analysis of key research variables}

Table 2. Responses to the rating of service quality

\begin{tabular}{lll}
\hline Options & Frequency & Percentage \\
\hline Very satisfactory & 80 & 25.00 \\
Satisfactory & 104 & 33.00 \\
Fairly satisfactory & 121 & 38.00 \\
Unsatisfactory & 9 & 03.00 \\
Very unsatisfactory & 4 & 01.00 \\
\hline Total & 318 & 100.00
\end{tabular}

Source: Field Survey, 2020.

Table 2 and figure 1 show that 80(25\%), $104(33 \%), 121(38 \%), 9(3 \%)$, and 4(1\%) of the respondents disclosed that they were very satisfied, satisfied, fairly satisfied, unsatisfied and very unsatisfied with the service quality of the organized road transport companies. 


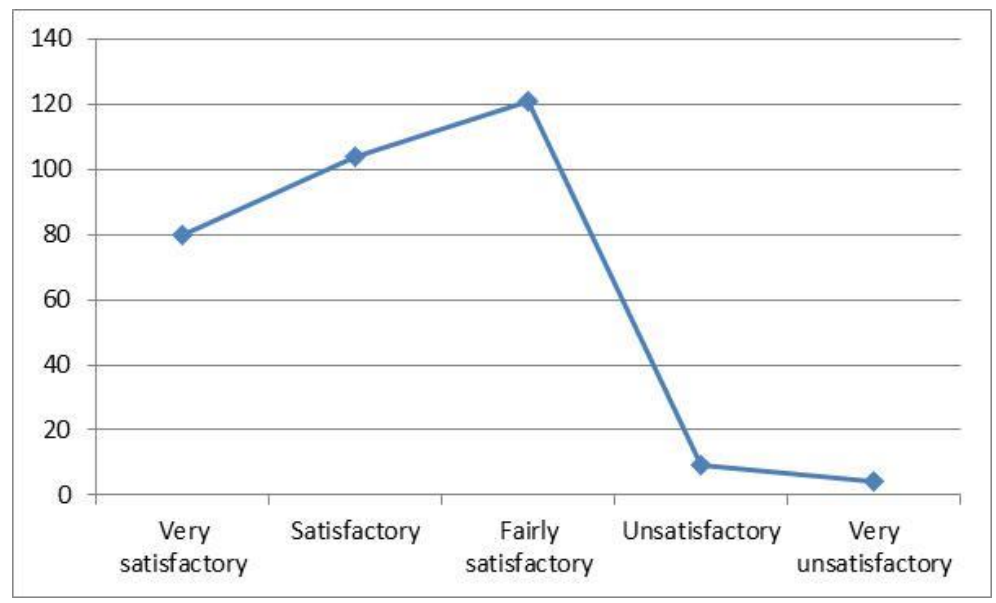

Fig. 1. Line graph showing respondents' rating of service quality

Table 3. Analysis of responses to questions on customer loyalty

\begin{tabular}{|c|c|c|c|c|c|c|c|}
\hline SN & Statement & SA & A & UN & $\mathrm{D}$ & SD & Total \\
\hline 1. & I will re-patronize this company. & 210 & 89 & 11 & 5 & 3 & 318 \\
\hline 2. & $\begin{array}{l}\text { I will recommend the services of the firm to } \\
\text { other customers. }\end{array}$ & 242 & 63 & 9 & 3 & 1 & 318 \\
\hline 3. & I will remain a loyal customer of the company. & 206 & 56 & 31 & 15 & 10 & 318 \\
\hline 4. & $\begin{array}{l}\text { I am ready to contribute in rebuilding the } \\
\text { company through suggestions to ensure that high } \\
\text { service quality is maintained. }\end{array}$ & 168 & 102 & 37 & 7 & 4 & 318 \\
\hline \multirow[t]{4}{*}{5.} & $\begin{array}{l}\text { In future, I expect to be rewarded in some sorts, } \\
\text { as a long time loyal customer. }\end{array}$ & 110 & 138 & 53 & 11 & 06 & 318 \\
\hline & Total & 936 & 448 & 141 & 41 & 24 & 1590 \\
\hline & Average & 187 & 90 & 28 & 8 & 5 & 318 \\
\hline & Percentage & 58 & 28 & 09 & 03 & 02 & 100 \\
\hline
\end{tabular}

Source: Field Survey, 2020.

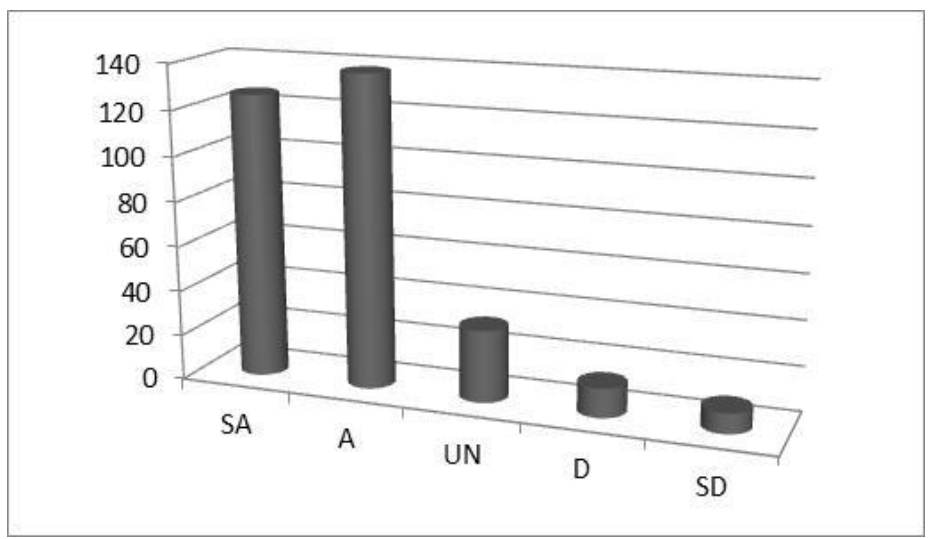

Fig. 2. Bar chart viewing responses to questions on customer loyalty 
Table 3 and figure 2 presented responses to the questions relating to customer loyalty. On the average, the table showed that $187(58 \%)$ respondents, $90(28 \%)$ respondents, $28(9 \%)$ respondents, 8 (3\%) respondents and $5(2 \%)$ respondents strongly agreed, agreed, were indifferent, disagreed and strongly disagreed respectively on the questions relating to customer loyalty.

Table 4: Analysis of responses on the effect of reliability on customer loyalty

\begin{tabular}{llcccccc}
\hline SN & Statement & SA & A & UN & D & SD & Total \\
\hline 1. & The firm provides promised services consistently. & 103 & 98 & 59 & 40 & 5 & 318 \\
2. & Service provided is usually accurate. & 145 & 86 & 33 & 32 & 9 & 318 \\
3. & Service paid for is usually delivered timely. & 206 & 64 & 16 & 12 & 7 & 318 \\
4. & The service I receive was performed rightly the first & 210 & 90 & 5 & 0 & 0 & 318 \\
& time. & & & & & & \\
\hline & Total & 152 & 338 & 113 & 84 & 21 & 1272 \\
& Average & 48 & 36 & 9 & 4 & 3 & 100 \\
\hline
\end{tabular}

Source: Field Survey, 2020

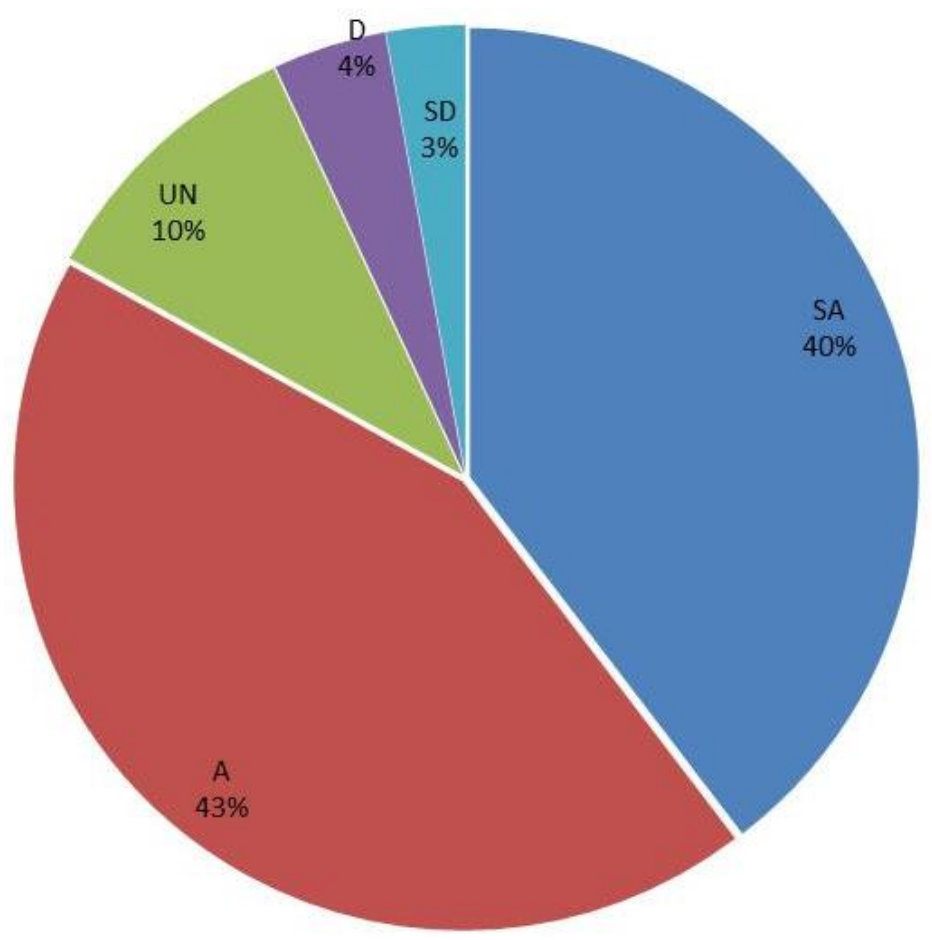

Fig. 3. Pie chart on responses on the effect of reliability on customer loyalty

Data presented in table 4 and figure 3 revealed that on the average, $152(48 \%)$ respondents, $115(36 \%)$ respondents, $29(9 \%)$ respondents, $14(4 \%)$ respondents and $9(3 \%)$ respondents strongly agreed, agreed, were indifferent, disagreed and strongly disagreed respectively on the questions relating to the effect of service quality reliability on customer loyalty. 
Table 5. Analysis of responses on the effect of tangibility on customer loyalty

\begin{tabular}{llcccccc}
\hline SN & Statement & SA & A & UN & D & SD & Total \\
\hline 1. & Facilities (vehicles and others) are attractive. & 104 & 110 & 82 & 12 & 10 & 318 \\
2. & Staff appearance is neat. & 132 & 158 & 20 & 5 & 3 & 318 \\
3. & The equipment and other facilities are quite & 162 & 123 & 19 & 9 & 5 & 318 \\
& modern. & & & & & & \\
4. & The office/building (park) is attractive. & 110 & 89 & 74 & 30 & 15 & 318 \\
\hline & Total & 508 & 480 & 195 & 56 & 33 & 1272 \\
& Average & 127 & 120 & 49 & 14 & 8 & 318 \\
& Percentage & 40 & 38 & 15 & 04 & 03 & 100 \\
\hline
\end{tabular}

Source: Field Survey, 2020

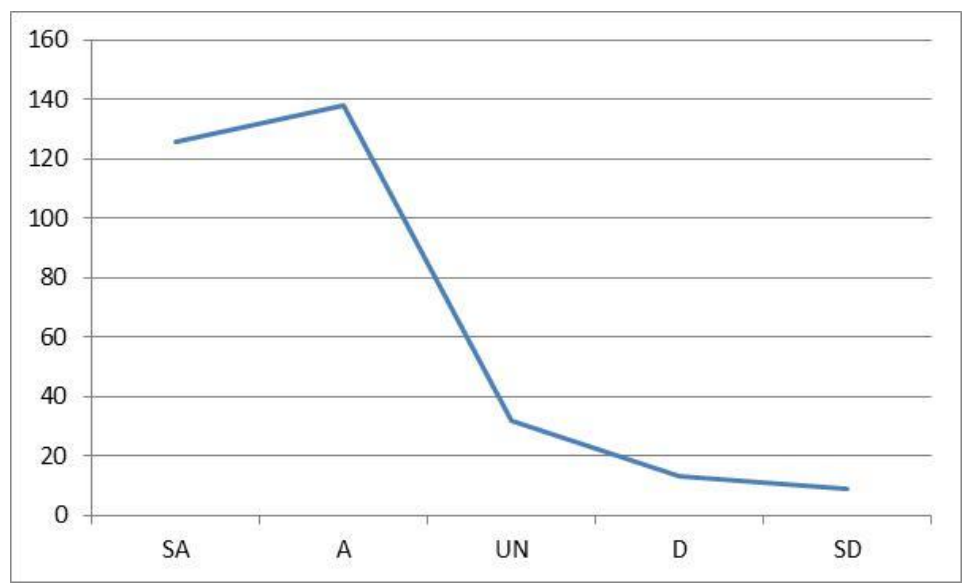

Fig. 4. Line graph on responses on the effect of tangibility on customer loyalty

As shown in table 5 and figure 4, there was an average of 127 (40\%) respondents, 120 (38\%) respondents, 49 (15\%) respondents, $14(4 \%)$ respondents and $8(3 \%)$ respondents who strongly agreed, agreed, were indifferent, disagreed and strongly disagreed respectively on the questions relating to the effect of service quality tangibility on customer loyalty.

Table 6: Analysis of responses on the effect of responsiveness on customer loyalty

\begin{tabular}{|c|c|c|c|c|c|c|c|}
\hline SN & Statement & SA & A & UN & $\mathrm{D}$ & SD & Total \\
\hline 1. & $\begin{array}{l}\text { When there is a problem, the company responds } \\
\text { quickly to address it. }\end{array}$ & 99 & 130 & 54 & 21 & 14 & 318 \\
\hline 2. & $\begin{array}{l}\text { Staff is ready and willing to attend to customer } \\
\text { inquiries and complaints. }\end{array}$ & 109 & 148 & 31 & 17 & 13 & 318 \\
\hline 3. & $\begin{array}{l}\text { The firm usually works within specific time to tackle } \\
\text { service failure satisfaction. }\end{array}$ & 128 & 146 & 28 & 11 & 5 & 318 \\
\hline \multirow[t]{4}{*}{4.} & $\begin{array}{l}\text { The staff members do not disappear or stay away when } \\
\text { customers face service failure. }\end{array}$ & 168 & 129 & 16 & 3 & 2 & 318 \\
\hline & Total & 504 & 553 & 129 & 52 & 34 & 1272 \\
\hline & Average & 126 & 138 & 32 & 13 & 9 & 318 \\
\hline & Percentage & 40 & 43 & 10 & 04 & 03 & 100 \\
\hline
\end{tabular}

Source: Field Survey, 2020 


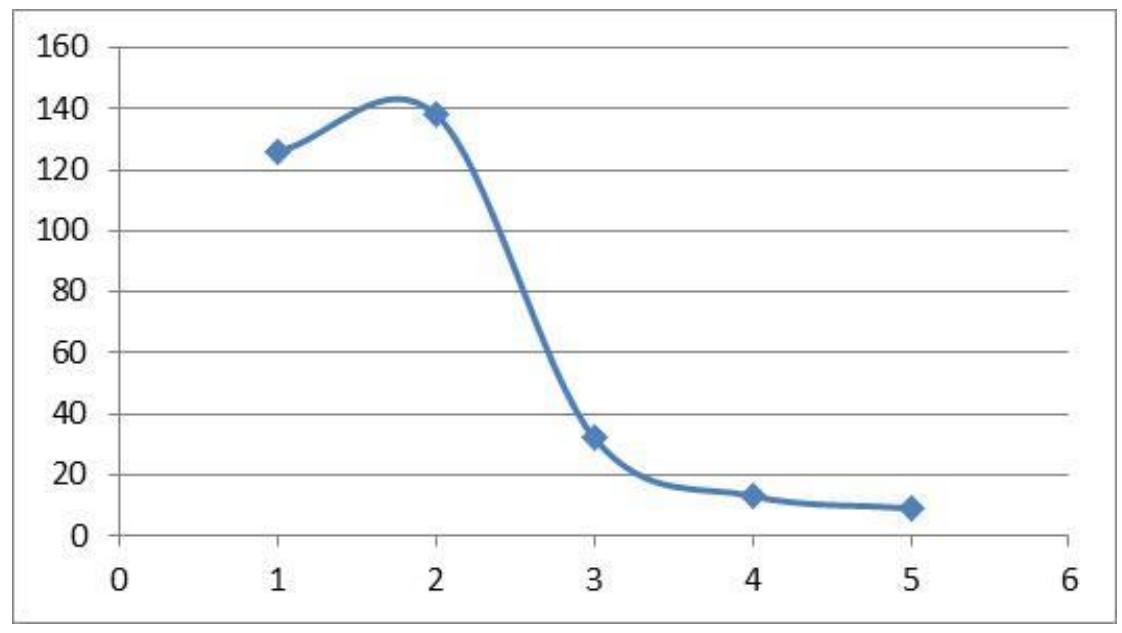

Fig. 5. Line graph on responses on the effect of Responsiveness on customer loyalty

As analyzed in table 6 and figure 5, the data showed that on the average, $126(40 \%)$ respondents, $138(43 \%)$ respondents, $32(10 \%)$ respondents, $13(4 \%)$ respondents and $9(3 \%)$ respondents strongly agreed, agreed, were indifferent, disagreed and strongly disagreed respectively on the questions relating to the effect of service provider's responsiveness on customer loyalty.

\subsubsection{Test of hypotheses}

Here, the three hypotheses were tested using Simple Regression Analysis at 0.05 level of significance and one-way Analysis of Variance (ANOVA) in SPSS version 21.

(a) Test of hypothesis one

This hypothesis was tested using information contained on table 4. The SPSS output is presented below:

Model Summary ${ }^{\mathrm{b}}$

\begin{tabular}{|l|r|r|r|r|r|}
\hline Model & R & R Square & Adjusted R Square & $\begin{array}{c}\text { Std. Error of the } \\
\text { Estimate }\end{array}$ & Durbin-Watson \\
\hline 1 & $0.917^{\mathrm{a}}$ & 0.841 & 0.840 & 0.34836 & 1.825 \\
\hline
\end{tabular}

a. Predictors: (Constant), Service Quality Reliability

b. Dependent Variable: Customer Loyalty

ANOVA $^{\mathrm{a}}$

\begin{tabular}{|rl|r|r|r|r|r|}
\hline Model & \multicolumn{1}{c|}{ Sum of Squares } & Df & Mean Square & F & Sig. \\
\hline \multirow{3}{*}{1} & Regression & 202.130 & 1 & 202.130 & 166.56 & $.000^{\mathrm{b}}$ \\
& Residual & 38.348 & 316 & 0.121 & & \\
& Total & 240.478 & 317 & & & \\
\hline
\end{tabular}

a. Dependent Variable: Customer Loyalty

b. Predictors: (Constant), Service Quality Reliability 


\section{Coefficients $^{\mathrm{a}}$}

\begin{tabular}{|c|c|c|c|c|c|}
\hline \multirow[t]{2}{*}{ Model } & \multicolumn{2}{|c|}{ Unstandardized Coefficients } & \multirow{2}{*}{$\begin{array}{c}\begin{array}{c}\text { Standardized } \\
\text { Coefficients }\end{array} \\
\text { Beta }\end{array}$} & \multirow[t]{2}{*}{$\mathrm{T}$} & \multirow[t]{2}{*}{ Sig. } \\
\hline & B & Std. Error & & & \\
\hline (Constant) & 0.896 & 0.088 & & 10.164 & .000 \\
\hline Service Quality Reliability & 0.830 & 0.020 & 0.917 & 40.812 & .000 \\
\hline
\end{tabular}

a. Dependent Variable: Customer Loyalty

Residuals Statistics ${ }^{\mathrm{a}}$

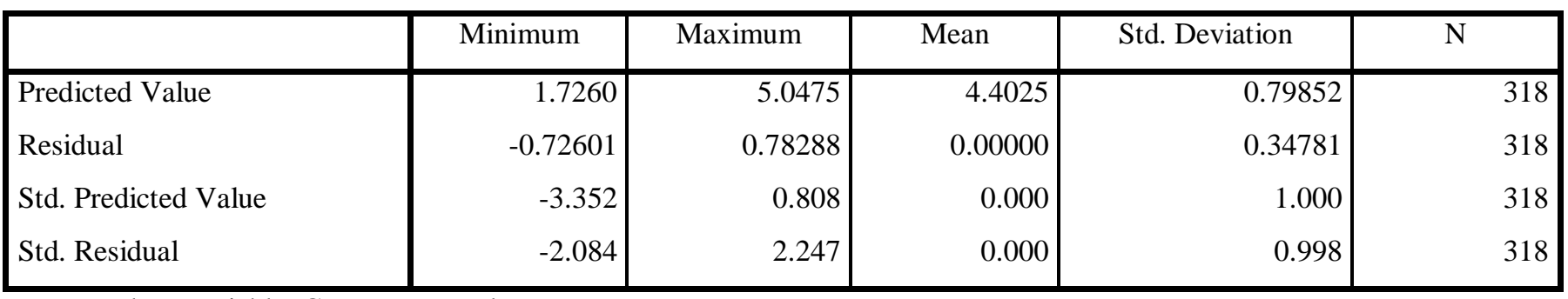

a. Dependent Variable: Customer Loyalty

\section{- $\quad$ Interpretation}

The $\mathrm{R}$ value in the model summary table shows a simple correlation of 0.917 which shows a strong and positive correlation. The $\mathrm{R}^{2}$ value shows how much of the total variation in the dependent variable (customer loyalty) that can be explained by the independent variable (service quality reliability). The table shows that $84.1 \%$ variation in customer loyalty to road transport firms can be explained by service quality reliability. This is very high. With a sig (p-value) of (0.000) which is less than Alpha (0.05), this implies that the overall regression model statistically predicts the outcome variable (That is, it is a good fit). This implies that service quality reliability is a significant predictor of customer loyalty among the respondents. Also, the Durbin Watson test shows that there is no first order autocorrelation since the value of DW produced by the SPSS is greater than the upper value (DU) from the critical table (1.825) is greater than DU (1.820).

\section{- Decision}

Since the P-value (0.000) is less than Alpha (0.05), that is $0.000<0.05$ and F cal $(166.56)>\mathrm{F}$ tab (3.84), we therefore reject the null hypothesis and accept the alternate hypothesis which implies that there is a significant, positive relationship between reliability and customer loyalty intention.

\section{(b) Test of hypothesis two}

This hypothesis was tested using information contained on table 5. The SPSS output is presented below:

Model Summary ${ }^{b}$

\begin{tabular}{|l|r|r|r|r|r|}
\hline Model & $\mathrm{R}$ & $\mathrm{R}$ Square & \multicolumn{1}{|c|}{$\begin{array}{c}\text { Adjusted R } \\
\text { Square }\end{array}$} & $\begin{array}{c}\text { Std. Error of the } \\
\text { Estimate }\end{array}$ & Durbin-Watson \\
\hline 1 & $0.878^{\mathrm{a}}$ & 0.771 & 0.770 & 0.41773 & 1.828 \\
\hline
\end{tabular}

a. Predictors: (Constant), Service Quality Tangibles

b. Dependent Variable: Customer Loyalty 
ANOVA $^{\mathrm{a}}$

\begin{tabular}{|ll|r|r|r|r|r|}
\hline Model & Sum of Squares & df & Mean Square & F & Sig. \\
\hline \multirow{2}{*}{1} & Regression & 185.338 & 1 & 185.338 & 106.23 & $.000^{b}$ \\
& Residual & 55.140 & 316 & 0.174 & & \\
& Total & 240.478 & 317 & & & \\
\hline
\end{tabular}

a. Dependent Variable: Customer Loyalty

b. Predictors: (Constant), Service Quality Tangibles

Coefficients $^{\mathrm{a}}$

\begin{tabular}{|c|c|c|c|c|c|}
\hline \multirow[t]{2}{*}{ Model } & \multicolumn{2}{|c|}{ Unstandardized Coefficients } & \multirow{2}{*}{$\begin{array}{c}\begin{array}{c}\text { Standardized } \\
\text { Coefficients }\end{array} \\
\text { Beta }\end{array}$} & \multirow[t]{2}{*}{$\mathrm{t}$} & \multirow[t]{2}{*}{ Sig. } \\
\hline & B & Std. Error & & & \\
\hline (Constant) & 1.204 & 0.101 & & 11.936 & .000 \\
\hline Service Quality Tangibles & 0.784 & 0.024 & 0.878 & 32.590 & .000 \\
\hline
\end{tabular}

a. Dependent Variable: Customer Loyalty

Residuals Statistics ${ }^{\mathrm{a}}$

\begin{tabular}{|l|r|r|r|r|r|}
\hline & \multicolumn{1}{|c|}{ Minimum } & Maximum & \multicolumn{1}{c|}{ Mean } & \multicolumn{1}{c|}{ Std. Deviation } & $\mathrm{N}$ \\
\hline Predicted Value & 1.9878 & 5.1220 & 4.4025 & 0.76463 & 318 \\
Residual & -.98779 & 0.66155 & 0.00000 & 0.41707 & 318 \\
Std. Predicted Value & -3.158 & 0.941 & 0.000 & 1.000 & 318 \\
Std. Residual & -2.365 & 1.584 & 0.000 & 0.998 & 318 \\
\hline
\end{tabular}

a. Dependent Variable: Customer Loyalty

\section{- Interpretation}

The $\mathrm{R}$ value in the model summary table shows a simple correlation of 0.878 which shows a strong and positive correlation. The $\mathrm{R}^{2}$ value shows how much of the total variation in the dependent variable (customer loyalty) that can be explained by the independent variable (service quality tangibles). The table shows that $77.1 \%$ variation in customer loyalty to road transport firms can be explained by service quality tangibles. This is very high. With a sig (p-value) of (0.000) which is less than Alpha (0.05), this implies that the overall regression model statistically predicts the outcome variable (That is, it is a good fit). This implies that service quality tangible is a significant predictor of customer loyalty among the respondents. Also, the Durbin Watson test shows that there is no first order autocorrelation since the value of DW produced by the SPSS is greater than the upper value (DU) from the critical table (1. 829) is greater than DU (1.820). 


\section{- Decision}

Since the P-value (0.000) is less than Alpha (0.05), that is $0.000<0.05$ and F cal $(106.23)>\mathrm{F}$ tab $(3.84)$, we therefore reject the null hypothesis and accept the alternate hypothesis which implies that there is a significant, positive relationship between tangibles and customer loyalty intention.

\section{(c) Test of hypothesis three}

This hypothesis was tested using information contained on table 6. The SPSS output is presented below:

Model Summary ${ }^{\mathbf{b}}$

\begin{tabular}{|l|r|r|r|r|r|}
\hline Model & $\mathrm{R}$ & R Square & \multicolumn{1}{|c|}{$\begin{array}{c}\text { Adjusted R } \\
\text { Square }\end{array}$} & $\begin{array}{c}\text { Std. Error of the } \\
\text { Estimate }\end{array}$ & Durbin-Watson \\
\hline 1 & $0.883^{\mathrm{a}}$ & 0.780 & 0.779 & 0.40919 & 1.825 \\
\hline
\end{tabular}

a. Predictors: (Constant), Service Provider's Responsiveness

b. Dependent Variable: Customer Loyalty

ANOVA ${ }^{a}$

\begin{tabular}{|rl|r|r|r|r|r|}
\hline Model & Sum of Squares & df & Mean Square & F & Sig. \\
\hline \multirow{2}{*}{1} & Regression & 187.568 & 1 & 187.568 & 112.35 & $.000^{\mathrm{b}}$ \\
& Residual & 52.910 & 316 & 0.167 & & \\
& Total & 240.478 & 317 & & & \\
\hline
\end{tabular}

a. Dependent Variable: Customer Loyalty

b. Predictors: (Constant), Service Provider's Responsiveness

\section{Coefficients $^{\mathrm{a}}$}

\begin{tabular}{|c|c|c|c|c|c|}
\hline \multirow[t]{2}{*}{ Model } & \multicolumn{2}{|c|}{ Unstandardized Coefficients } & \multirow{2}{*}{$\begin{array}{c}\text { Standardized } \\
\text { Coefficients }\end{array}$} & \multirow[t]{2}{*}{$\mathrm{T}$} & \multirow[t]{2}{*}{ Sig. } \\
\hline & $\mathrm{B}$ & Std. Error & & & \\
\hline (Constant) & 1.057 & 0.103 & & 10.308 & .000 \\
\hline $\begin{array}{l}\text { Service Provider's } \\
\text { Responsiveness }\end{array}$ & 0.810 & 0.024 & 0.883 & 33.470 & .000 \\
\hline
\end{tabular}

a. Dependent Variable: Customer Loyalty 
Residuals Statistics ${ }^{\mathrm{a}}$

\begin{tabular}{|l|r|r|r|r|r|}
\hline & Minimum & Maximum & \multicolumn{1}{c|}{ Mean } & Std. Deviation & \multicolumn{1}{c|}{ N } \\
\hline Predicted Value & 1.8673 & 5.1083 & 4.4025 & 0.76922 & 318 \\
Residual & -.86733 & 0.70195 & 0.00000 & 0.40854 & 318 \\
Std. Predicted Value & -3.296 & 0.918 & 0.000 & 1.000 & 318 \\
Std. Residual & -2.120 & 1.715 & 0.000 & .998 & 318 \\
\hline
\end{tabular}

a. Dependent Variable: Customer Loyalty

\section{- Interpretation}

The $\mathrm{R}$ value in the model summary table shows a simple correlation of 0.883 which shows a strong and positive correlation. The $\mathrm{R}^{2}$ value shows how much of the total variation in the dependent variable (customer loyalty) that can be explained by the independent variable (service provider responsiveness). The table shows that $78 \%$ variation in customer loyalty to road transport firms can be explained by service provider responsiveness. This is very high. With a sig (p-value) of (0.000) which is less than Alpha (0.05), this implies that the overall regression model statistically predicts the outcome variable (That is, it is a good fit). This implies that service provider responsiveness is a significant predictor of customer loyalty among the respondents. Also, the Durbin Watson test shows that there is no first order autocorrelation since the value of DW produced by the SPSS is greater than the upper value (DU) from the critical table (1.825) is greater than DU (1.820).

\section{- Decision}

Since the P-value (0.000) is less than Alpha (0.05), that is $0.000<0.05$ and $\mathrm{F} \mathrm{cal}(112.35)>\mathrm{F}$ tab (3.84), we therefore reject the null hypothesis and accept the alternate hypothesis which implies that there is a significant, positive relationship between responsiveness and customer loyalty intention.

\subsubsection{Summary of findings}

This study is quite revealing. Lots of findings were made; supporting previous findings and negating others. On the individual variables, for instance, our findings show that there is a significant, positive relationship between reliability and customer loyalty intention. This implies that the extent to which the road transport firms provide promised service consistently, provide accurate services, deliver timely services and provide service quality rightly the first time a customer visits, affect customer loyalty intention significantly. This finding supports the findings of Kofi, Zakari and Ajara (2013), Derkota and Dahal (2016), Duodu and Amankwah (2011) and Kheng et al. (2010). However, in the study of the Indian customers' loyalty to telecom firms, Kumar (2015) found that reliability had no significant effect on customer loyalty, among all the RATER components.

It was also revealed that there is a significant and positive relationship between tangibles and customer loyalty intention in the road transport industry in South East Nigeria. This implies that the quality of facilities, staff appearance, neatness of the environment and equipment available will drive customer loyalty significantly. Managing these touch-points effectively is required to maintain loyalty and competitive edge. This finding negates the findings of Kheng et al. (2010), Kofi et al. (2013), Saravanakumar, and Jayakrishnan (2014). However, it is in line with the findings of Derkota and Dahal (2016), Kofi et al. (2013), Leninkumar (2016) and Kumar (2015).

Again, the study of Leninkumar et al (2016) indicated that responsiveness does not predict customer loyalty significantly amongst bank customers in Sri Lanka. Dubey and Srivastava (2016), Kheng et al. (2010), Leninkumar (2016) as well as Saravanakumar and Jayakrishnan (2014) found similar result. However, our study found that service providers' responsiveness significantly and positively predicts customer loyalty intention. This implies that the ability of firms to respond quickly to customer issues, readiness and willingness of staff to attend to customer inquiries and complaints, ability to handle and tackle service failure within specified time and being on ground to solve any service 
failure problem will significantly drive customer loyalty. This finding supports the findings of Kumar (2015), Kofi et al. (2013), Derkota and Dahal (2016) and Duodu and Amankwah (2011).

\section{Conclusions}

The RATER model of service quality surveys challenging areas of service significance to clientele. This study has been able to ascertain, though in position to many existing studies, that the RATER variables are significant predictors of customer loyalty intention in South East Nigerian transport industry. Specifically, the study found that the three components off the model studied here (reliability, tangibility and responsiveness) have positive and significant relationship with customer loyalty. It therefore follows that, any transport firm that fails in these areas will suffer from customer churn and shifting loyalty. This implies that to persistently magnetize and preserve loyal customers, transport operators in the industry must be cognizant with service quality. When consumers are pleased with the service quality stipulation of operators, marketing recital index will advance, resulting in enhanced competitive position.

\section{References}

Agbonifoh, B. A., Ogwo, O. E., Nnolim, D. A., \& Nkamnebe, D. A. (2007). Marketing in Nigeria: Concepts, Principles and Decisions, 2nd ed. Aba: Afritowers Ltd.

Agu, G. A. (2015). Customer complaint behaviour in the service industry: A study of the customers of the organized road transport firms in Imo State". A Ph.D. Thesis, Abia State University, Nigeria.

Agu, G.A and Okpara, G.S (2015). Comparative complaint management strategies in the organized road transport firms in Imo State. Journal of Marketing Research, 4(1).

Agu, G.A., Ogbuji, C.N., Okpara, G.S., \& Ogwo, E.O. (2008). Understanding customer complaint behavior for sustainable business development. Journal of Economics and Management Science, 1(3), 1-15.

Anyanwu, A. (2008) "Service Recovery Strategies" In Nwokah, G N and Anyanwu, A (ed), Contemporary Book on Services Marketing. Owerri: Avan Global Press.

Anyanwu, A. (2013). Marketing Management and Strategy. Owerri: Avan Global Publications

Cronin, J. J., Jr., and Taylor, S. A. (1992) "Measuring service quality: A reexamination and extension", Journal of Marketing, 56, 55-68.

Etzel, M. J., Walker, B. J. and Stanton, W, J. (2001). Marketing (12 ${ }^{\text {th }}$ ed.). Sao Paulo: Editora Makron Books Ltda.

Inyang, B. J. (2008). Organisational Behaviour: A managerial Perspective (2nd Ed). Calabar: Merb publishers.

Kalu, I. N. (2015). Service quality and marketing performance of hotels in Abia and Imo State. Ph.D. Thesis: Department of Marketing, Abia State University, Uturu.

Kheng, L. L., Osman, M., Ramojah, T. \& Mosahab, R. (2010). The impact of service quality on customer loyalty: a study of banks in Penang Malaysia. International Journal of Marketing Studies 2(2).

Kotler, P and Keller, K.L. (2007) Marketing Management, $12^{\text {th }}$ ed. New Delhi: Prentice Hall of India.

Leninkumar, V. (2016). The effect of service quality on customer loyalty. European Journal of Business Management, 8(33).

Ogwo, E. O. and Agu, G. A. (2015). Transport infrastructure, manufacturing sector performance and growth of GDP in Nigeria, 1999 - 2014. Conference Paper Read at the 2nd International Interdisciplinary Conference on Global Initiative for Integrated Development Held at COOU 2nd - 5th September.

Okpara, G. S. (2012). Contemporary Marketing: Topical and Topicalised, 2nd ed. Owerri: Avan Global Press. 
Saravanakumar, G. and Jayakrishnan, J. (2014). Effect of service quality on customer loyalty: empirical evidence from co-operative bank. International Journal of Business and Administration Research Review, Vol.2, Issue.4, Jan-March, 2014.

Derkota, N. \& Dahal, J. R. (2016). An empirical study of service quality dimensions on customer satisfaction and customer loyalty in Nepalese commercial banking sector. An MSC Thesis: University of Nepal.

Duodu, F. K. and Amankwah, T. (2011). An analysis and assessment of customer satisfaction with service quality in insurance industry in Ghana. Master Thesis in Business Administration, Luleå University of Technology.

Kofi, P., Zakari, M. \& Ajara, S. (2013). Impact of service quality on customer loyalty in the hotel industry: An empirical study from China. International Review of Management Business Research 2(2), $600-609$.

Kumar, A. (2015). Effect of service quality on customer loyalty and the mediating role of customer satisfaction: An Empirical Investigation of the Telecom Industry. Journal of Academy of Hospital Administration, India 102 (3).

Ogwo, E. O. and Agu, G. A. (2015). Transport infrastructure, manufacturing sector performance and growth of GDP in Nigeria, 1999 - 2014. Conference Paper Read at the 2nd International Interdisciplinary Conference on Global Initiative for Integrated Development Held at COOU 2nd - 5th September. 